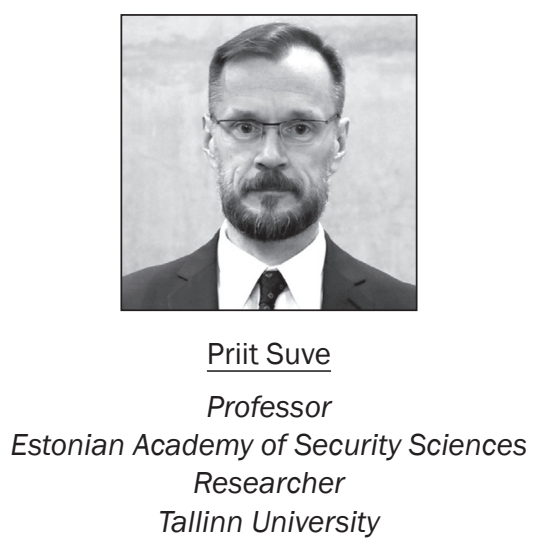

\title{
How to Avoid
}

\section{De-professionalisation of the Police}

\section{Introduction}

Although the origin of contemporary police in Anglo-American and continental European cultures lies in various ideologies, the core mission of the police at the general level is to enhance and advance the safety of a particular country. The guiding principle of contemporary policing is that the (civil) police should be separated from the military. ${ }^{* 1}$ However, the question of safety is not constrained to merely topics falling under public order or crime. That was so centuries ago, at the time of the birth of Continental police culture in France or of the Anglo-American police culture in England ${ }^{* 2}$, or when the cock crowed at the dawn of police science ${ }^{*} 3$ early in the last century ${ }^{*}$. The concept of safety has widened from the traditional crime-centred view to a multidimensional and hard-to-define issue that embraces all aspects of society. Also, it is complicated to distinguish internal safety from external. The latter was most strikingly demonstrated during the latest military conflict in Ukraine, wherein 'little green man' without any distinguishing badges or markings but with machine guns walked the territory of the country. Another problem arises in connection with the inherent complexity level of safety problems. The police have to deal with simply defined problems such as shoplifting but also with vaguely defined ones such as corruption or terrorism. The latter is known in the social sciences as an example of 'wicked problems" ${ }^{* * 5}$ - problems 'that are complex, unpredictable, open ended, or intractable*" .

The literature about European police reforms from the last few decades expresses a noteworthy tendency quite clearly - the police reforms have not been driven to address safety issues or designed to do

$1 \quad$ United Nations General Assembly. Code of Conduct for Law Enforcement Officials. Resolution 34/169, of December 1979; Committee of Ministers of the Council of Europe. The European Code of Police Ethics. Recommendation (2001)10, of 19 September 2001. Council of Europe Publishing

2 See J.-P. Brodeur. The Policing Web. New York: Oxford University Press 2010. - DOI: https://doi.org/10.1093/acprof: oso/9780199740598.001.0001.

3 There is no single definition of police science, nor is defining the term the purpose of this article. For this article, police science can be understood as 'the scientific study of the police as an institution and of policing as a process' (T. Bjørgo et al. Perspectives of Police Science in Europe: Final Report. European Police College 2007).

4 See A. Vollmer. The scientific policeman. - The American Journal of Police Science 1930, pp. 8-12; A. Vollmer. Police progress in the past twenty-five years. - Journal of Criminal Law and Criminology 1933, pp. 161-175.

5 See H.W. Rittel, M.M. Webber. Dilemmas in a general theory of planning. - Policy Sciences 4 (1973) / 2, pp. $155-169$.

6 B.W. Head, J. Alford. Wicked problems: Implications for public policy and management. - Administration \& Society 47 (2015) / 6, pp. 711-739 (on p. 712). - DOI: DOI: https://doi.org/10.1177/0095399713481601. 
so. The economic situation was the main spark for reforming the police and thereby achieving greater efficiency and effectiveness, and centralisation was the dominant mechanism in reforming of organisation toward these ends. When perusing research papers ${ }^{*} 7$ that describe or analyse particular reforms, one can find hardly a note about strategies of policing. The view that an organisation is a closed bureaucratic system, especially when coupled with a lack of knowledge about strategies of policing ${ }^{*}$, may detach a police force from its core mission and can even bring about a need for new reforms.

Although every organisation ought to develop and change, it is wise to anticipate significant shocks and their effects. Most reforms definitely are considerable shocks to the system. The main question for this article is composed of two parts. Firstly, how can the concept of the organisation be handled in such a way that it at least gives a chance of dealing with wicked problems, those problems that are complicated to define and cannot be solved, only mitigated? Secondly, what are the mechanisms that could develop the police's professional status in society and act as a tie within the organisation while also connecting that organisation to the existing task environment?"9 In this article, I argue that police strategies are the means of giving a meaning and real 'soul' to the (buffering and bridging) techniques and that these form a solid basis for the meta-language ${ }^{* 10}$ of the police.

These questions are important not only for the police; they have more general implications for all of society. Safety is a Janus-like entity: one of the two faces tells us that safety related to traditional crimes is in decline ${ }^{* 11}$, and the other face refers to new global trends such as terrorism or fears related to migration ${ }^{* 12}$. However, the social world is not as simple as that, and it would be misleading to describe it in such a dialectical or dichotomous way. The reason for that is hidden within the nature of interconnectedness of safety issues.

With the purpose of bringing the idea for the article into focus, one must emphasise two questions that arise. The first question has some bearing on the entire history of the police - the dilemma between theory and practice. The gap between scientific knowledge and the concrete, real-world actions of the police has been a widely discussed topic that recently gained more concrete form. The work of 'pracademics" ${ }^{* 13}$ is seen as a possible bridging mechanism that possesses potential to connect the two. Another trend related to the latter is associated with the question of police science in general. As David H. Bayley ${ }^{*}{ }^{14}$ has stated, '[p]olice science must become part of police professionalism'. ${ }^{* 15}$

To reveal some underdeveloped aspects of police literature regarding the topic, in aims of helping the police to advance and achieve anchoring for the position of professional player in the field of safety, I draw some ideas from contemporary organisational theories and strategic management.

7 E.g., N.R. Fyfe et al. Centralizing Forces? Comparative Perspectives on Contemporary Police Reform in Northern and Western Europe. The Hague: Eleven International Publishing 2013.

8 E.g., P. Suve. Police officers about the function of the police and changes implemented in Estonian police since October 2014 (an analytical report released by the Estonian Police and Border Guard Board in 2015).

9 B.K. Boyd, S. Gove. Managerial Constraint: The Intersection between Organizational Task Environment and Discretion (Vol. 3 in the series Research Methodology in Strategy and Management), pp. 57-95. Emerald Group Publishing Limited 2006.

10 Every profession has adopted specific language for precise use (examples include the argot of medicine, education, the construction industry, and other fields). The language that helps professionals be more precise and understand each other with minimal transaction costs while also avoiding mistakes can be identified as a meta-language of that particular profession. The police's meta-language is composed of terminology from the fields that are the main contributors to police science criminology and management. The meta-language is always in a state of flux.

11 E.g., A. Tseloni et al. Exploring the international decline in crime rates. - European Journal of Criminology 7 (2010) / 5 , pp. 375-394.

12 E.g., M. Shaw et al. Determining trends in global crime and justice: An overview of results from the United Nations surveys of crime trends and operations of criminal justice systems. - Forum on Crime and Society 3 (2003) / 1, pp. 35-63; F. Lemieux et al. (eds). Economic Development, Crime, and Policing: Global Perspectives. CRC Press 2014.

13 In this article, the term 'pracademic' signifies a person who holds a doctoral degree and works as an active practitioner in the field of safety (see P.L. Posner. The pracademic: An agenda for re-engaging practitioners and academics. - Public Budgeting \& Finance 29 (2009) / 1, pp. 12-26; J.J. Willis. The romance of police pracademics. - Policing 10 (2016) / 3, pp. 315-321. - https://doi.org/10.1093/police/paw030; A.A. Braga. The value of 'pracademics' in enhancing crime analysis in police departments. - Policing: A Journal of Policy and Practice 10 (2016) / 3, pp. 308-314. - DOI: https://doi.org/10.1093/ police/paw032; J.R. Tahiliani, J.E. McCabe. The Pracademic and Academic in Criminal Justice Education: A Qualitative Analysis. Police Forum 26 (2016) / 1, pp. 1-12.

14 D.H. Bayley. Police research: Trends and prospects. - R. Graner, O. Kronkvist (eds). The Past, the Present and the Future of Police Research: Proceedings from the Fifth Nordic Police Research Seminar (pp. 7-14). Växjö, Sweden: Linnæus University Studies in Policing 2015, on p. 11.

15 See also L. Huey, R.J. Mitchell. Unearthing hidden keys: Why pracademics are an invaluable (if underutilized) resource in policing research. - Policing 10 (2016) / 3, pp. 300-307. - DOI: https://doi.org/10.1093/police/paw029. 
The article has four main parts. The first section, an introduction to the piece, outlines the problem and takes up the research questions. Secondly, the empirical part illuminates the problem through the case of the Estonian police and considers European police reforms and the problem of mono-strategism. In the third part, theoretical principles that are familiar to a management audience but not so well-known in the field of policing are introduced. Then, the fourth part of the paper summarises the arguments and offers some concluding remarks. Since the article is not presented as a traditional empirical piece, the reason for its structure needs to be clarified. Traditionally in empirical articles, a theory precedes the application of empiricism, but the opposite is true for the present article. Although the empirical work was composed of three distinct studies, all of which had its own purposes and separate results, they will be used in this article as problem-constructors, and the theoretical part of the piece should be viewed as offering possible solutions to the problems posed.

\section{Neglecting to consider police strategies}

Some years ago, I started research into the Estonian police with the purpose of revealing and explaining the organisational changes that took place after the 1991 restoration of the country's independence, as the Soviet military militia was reorganised into an Estonian police institution. Studying changes in one particular organisation provides an opportunity to look in greater depth than is possible with a mere comparison between organisations or countries. Often the importance of the findings gains precise meaning in some specific context. For that reason, while studying the Estonian police, I simultaneously analysed police reforms made in eight other European countries ${ }^{* 16}$ within the previous two decades. ${ }^{*} 17$ Also, I reviewed three leading journals indexed in the Web of Science databases that cover the field of policing ${ }^{* 18}$, combing their content from the same period to find an answer to the following question: how are the police strategies portrayed and analysed? In the sections below, I will present the problems dealt with in each of the areas of study considered in those articles. Since the studies subject to discussion form an extensive body of work, what follows is a very cursory overview of them.

\subsection{Police without a strategy: The case of the Estonian police ${ }^{* 19}$}

The case of the Estonian police is interesting in many ways, but in the context of this article, two central points should be highlighted. Firstly, the Estonian police force is an interesting object of study since it has such a dramatic history and experienced rapid changes in the replacement of a Russian-speaking military Soviet militia with a democratic Estonian national police organisation in 1991. Secondly, safety in Estonia has improved enormously since the early years of independence ${ }^{* 20}$, even though the nation's police did not knowingly practise any strategy of policing from 1991 to $2013^{{ }^{*} 21}$.

The analysis at the Estonian level was based on documentary analysis of the following public documents: the two main laws regulating police action in $1991-2013^{{ }^{222}}$; four fundamental regulations setting forth the

16 England, Scotland, the French Republic, the Federal Republic of Germany, the Republic of Finland, the Kingdom of Sweden, the Netherlands, and the Kingdom of Belgium.

17 P. Suve. Politsei kui institutsiooni arengu mõtestamise kontseptuaalsed probleemid keerustuvas vastastiksõltuvas keskkonnas ['Conceptual problems in understanding changes of the police in a complex and interdependent task environment']. Tallinn: Tallinn University 2016. A doctoral dissertation (in the 'Sotsiaalteaduste dissertatsioonid' series), especially pp. 31-34.

18 There are three police-specific journals that were indexed in the Thomson Reuters Web of Science databases: Policing: An International Journal of Police Strategies \& Management, Police Quarterly, and Policing and Society.

19 The main results of the analysis are presented in the following article: P. Suve et al. Two decades of Estonian police and the (ir)relevance of police models for the development of safety policy. - Studies of Transition States and Societies 8 (2016) / 1, pp. 36-52.

20 See J. Saar. Crime, crime control and criminology in post-communist Estonia. - European Journal of Criminology 2004, pp. 505-531. - DOI: https://doi.org/10.1177/1477370804045694; A. Markina. Estonia: Crime, criminal justice, and criminology in a changing socio-economic context. - C.J. Smith et al. (eds). Routledge Handbook of International Criminology (pp. 376-389). New York: Routledge 2011. - DOI: https://doi.org/10.4324/9780203864708.ch35; J. Saar. Crime and the population's sense of security. - M. Heidmets (ed.). Estonian Human Development Report 2012/2013: Estonia in the World. Tallinn: Eesti Koostöö Kogu (2013), pp 86-91.

21 See P. Suve et al. (see Note 19).

22 Politseiseadus (The Police Law). - RT 1990, 10, 113 (in Estonian); Politseiteenistuse seadus (Police Service Act). - RT I 1998, 50, 753 (in Estonian). 
structure for the organisation, at the government and local level ${ }^{{ }^{2} 3}$; four major development plans ${ }^{{ }^{*} 24}$; and five instructions for police work, examined for an understanding of changes at the operational level ${ }^{{ }^{*} 25}$.

In the analysis of changes within the Estonian police, Gary W. Cordner's four-dimensional model of community police ${ }^{* 26}$ (with philosophical, strategic, tactical, and organisational dimensions) was used. The model of community police was selected for reason of being probably the most well-known model to emerge in the last 50 years and since potential utility was seen in being able to analyse changes through the lens of some concept rather than perform analysis without any particular vantage point. The model can be used as a mirror to reflect the changes under discussion.

We found that the overall development of the Estonian police has taken contradictory directions within individual dimensions and between them. For example, at the philosophical level (that of development plans), the emphasis was on the importance of prevention, but at the tactical level bureaucratic activities (e.g., registering and handling reports) were placed ahead of prevention activities. A tendency toward more militaristic principles can be recognised from the organisational behaviour, with the military-like career system serving as an example of this. ${ }^{*} 7$

Reflecting common practice, 'model' and 'strategy' are used synonymously in this article in the police context ${ }^{*}{ }^{28}$. It is unclear how the development of the Estonian police would have differed if some actual police strategy had been intentionally used, but we are aware that in the evident absence of any precise and understandably stated strategy, the developments were unplanned and unpredictable. We can safely state the following conclusion for purposes of this article: the Estonian police have developed without deliberately using any police model or strategy, and the changes in the police were inconsistent in many ways. The latter notwithstanding, overall safety in Estonia has improved a large amount, and a single or particular reason can hardly be stated. Neither is there a focused study addressing this.

The case of the Estonian police highlights only one side of the problem - that of the organisation's size. In criminology, it is well-known that, while the number of police personnel has a small impact on various crimes, the way of policing has a more significant influence on safety. ${ }^{*}{ }^{29}$ Thus far, the link between the police and safety has not been subject to discussion. Hence, light is being shed on it now as the important element examined in this article. The next subsection addresses the topic through consideration of police reforms in Europe.

\subsection{A core mission that ignores organisational reforms}

The primary aim here, of studying police reforms, emerged from the need to set the changes to the Estonian police in the European context. The literature on public administration recognises a few approaches to how the European territory should be analysed, but none of them are familiar to a police-specific audience.

23 Politsei-ja Pïrivalveameti Lääne prefektuuri põhimäärus (The Statute of the West Prefecture). Tallinn: Politsei- ja Piirivalveamet 2012 (in Estonian); Eesti Vabariigi Riikliku Politseiameti põhimäärus (The Statute of the Police Board). - RT 1991, 39, 488 (in Estonian); Politseiprefektuuri põhimäärus (The Statute of a Police Prefecture). - RT 1992, 22, 314 (in Estonian); Politsei-ja Piirivalveameti põhimäärus (The Statute of the Estonian Police and Border Guard Board). - RTL 2009, 77, 1132 (in Estonian).

24 Eesti politsei arengukava aastateks 1999-2001 (Development Plan of the Estonian Police for 1999-2001). Tallinn: Politseiamet 1999 (in Estonian); Eesti turvalisupoliitika põhisuundade aastani 2015 heakskiitmine ['Approval of the main directions for Estonian safety policy to 2015']. - RT I 2008, 25, 165 (in Estonian); Guidelines for Development of Criminal Policy until 2018. Tallinn: Riigikogu 2010; Politseivaldkonna prioriteetsed arengusuunad aastani 2006 ['Development priorities for the Estonian Police to 2006']. - Tallinn: Siseministeerium 2006 (in Estonian).

25 Patrullteenistuse määrustik (Directive of the Patrol Police Service). - Käskkiri No. 51. Tallinn: Politseiamet 11.3.1993 (in Estonian); Konstaabliteenistuse juhend (Instruction of the Constable Service). - Käskkiri No. 72. Tallinn: Politseiamet 19.3.1998 (in Estonian); Piirkondliku politseitöö juhend (Instruction of the Regional Police Service). Tallinn: Politseiamet 2001 (in Estonian); Patrulltegevuse kord (Rules for Patrol Police). Tallinn: Politsei- ja Piirivalveamet 2010 (in Estonian); Piirkondliku politseitöö juhend (Instruction of the Regional Police Service). Tallinn: Politsei- ja Piirivalveamet 2010 (in Estonian).

26 See G.W. Cordner. Community policing: Elements and effects. - Police Forum: Academy of Criminal Justice Science Police Section 5 (1995) / 3, pp. 1-16; G.W. Cordner, K.E. Scarborough. Police Administration (Seventh Edition). New York: Anderson Publishing 2013. - DOI: https://doi.org/10.4324/9781315722184.

27 P. Suve et al. (see Note 19), pp. 47-49.

28 In police literature, the terms 'police model' and 'police strategy' are often used in an ambiguous way. The ontology and epistemology of these terms need to be specified (see P. Suve as cited in Note 17, pp. 16-29).

29 J.E. Eck et al. Adding more police is unlikely to reduce crime: A meta-analysis of police agency size and crime research. Translational Criminology 14 (2017), pp. 14-16. 
Police culture is often split into two cultural zones for discussion - Continental and Anglo-American police. The historical roots of the former stem from France and the latter from England. ${ }^{*}{ }^{*}$ From the regional point of view, the Scandinavian police culture too can be highlighted as a specific one and distinctive in many ways. For that reason, the samples for the analyses were chosen in line with cultural argumentation. The other reason for picking exactly these examples is related to the existing empirical material. Irrespective of the fact that police reforms are commonplace in many countries, there are not many studies (in English) to include in the analysis ${ }^{*}{ }^{31}$. In consideration of the foregoing information, the following countries were selected as appropriate for my research: England and Scotland as representatives of Anglo-American police culture, France and Germany as countries representing Continental police culture, and Finland and Sweden as countries representing the above-mentioned Scandinavian police culture. Finally, the Netherlands and Belgium were chosen because they do not directly belong to any specific police culture.

The analysis revealed at least two important observations. Firstly, the main trend of the reforms was concentrated on reforming organisation, instead of policing. Centralisation and merging of police units were the predominant mechanisms in reforms to the organisation (the cases of Scotland ${ }^{*}{ }^{32}$, Finland ${ }^{*} 33$, and Belgium $^{*} 34$ are illustrative here). Secondly, safety had an equivocal meaning within the context of police reforms. Most important from the standpoint of the core mission of the police is that safety had a secondary meaning. On one hand, that is good news, since it allows one to assume that there are good overall conditions of safety. On the other hand, if reforms to the police - the only professional player in the field of safety - forget that player's core mission and role in society, the way is paved for de-professionalisation and for further changes in the police context. The reasons for the latter development may be related exclusively to safety questions, since there are no longer any professional players in the field after such reforms. Safety is an issue that permeates the whole of society, and it is becoming more complex. Accordingly, it has a major role in our day-to-day life, and professional knowledge is called for to mitigate possible causes of deviation.

Among the cases under study, the reforms in Belgium ${ }^{*} 35$, the Netherlands s ${ }^{*}$, and Sweden ${ }^{*}{ }^{37}$ still had some links to safety. The problems were related not to the overall safety situation but to some individual failures of the juridical system, the police included (as in the case of Marc Dutroux in Belgium ${ }^{*}{ }^{3}$ ) or police organisational failures (as with the fragmentation and problems of co-operation among the police in the Netherlands ${ }^{*} 39$ or

30 See J.-P. Brodeur (see Note 2).

31 The study embraces the research within the body of English-language literature, but the problem of research in the multilingual domain is not new in police research (see, for example, L. Holmberg. Policing and the feeling of safety: The rise (and fall?) of community policing in the Nordic countries. - Journal of Scandinavian Studies in Criminology and Crime Prevention 5 (2005) / 5, pp. 205-219, on p. 206. - DOI: https://doi.org/10.1080/14043850410010702. Those with more in-depth interest might wish to consult G. Meško et al. (eds). Handbook on Policing in Central and Eastern Europe. New York: Springer 2013. - DOI: https://doi.org/10.1007/978-1-4614-6720-5.

32 N.R. Fyfe, K.B. Scott. In search of sustainable policing? Creating a national police force in Scotland. - N.R. Fyfe et al. (eds). Centralizing Forces? Comparative Perspectives on Contemporary Police Reform in Northern and Western Europe (pp. 119-136). The Hague: Eleven International Publishing 2013; J. Terpstra, N.R. Fyfe. Mind the implementation gap?: Police reform and local policing in the Netherlands and Scotland. - Criminology and Criminal Justice 2015, pp. 1-34. - DOI: https://doi.org/10.1177/1748895815572162.

33 S. Virta. Governing urban security in Finland: Towards the 'European model'. - European Journal of Criminology 10 (2013) / 3, pp. 341-353. - DOI: https://doi.org/10.1177/1477370812473536; M. Vuorensyrjä. Organizational reform in a hierarchical frontline organization: Tracking changes in stress and turnover intention during the Finnish police reform years. - Policing: An International Journal of Police Strategies \& Management 37 (2014) / 4, pp. 858-874. - DOI: https:// doi.org/10.1108/pijpsm-05-2014-0058.

34 J. Maesschalck. When do scandals have an impact on policy making? A case study of the police reform following the Dutroux scandal in Belgium. - International Public Management Journal 5 (2002) / 2, pp. 169-193; E. Devroe, P. Ponsaers. Reforming the Belgian police system between central and local. - N.R. Fife et al. (eds). Centralizing Forces? Comparative Perspectives on Contemporary Police Reform in Northern and Western Europe (pp. 77-98). The Hague: Eleven International Publishing 2013.

35 E. Devroe, P. Ponsaers (see Note 34); C. Pollitt, G. Bouckaert. Public Management Reform: A Comparative Analysis - New Public Management, Governance, and the Neo-Weberian State, 3rd Edition. New York: Oxford University Press 2011.

36 J. Terpstra, N.R. Fyfe. Policy processes and police reform: Examining similarities and differences between Scotland and the Netherlands. - International Journal of Law, Crime and Justice 2014, pp. 1-18. - DOI: https://doi.org/10.1016/j. ijlcj.2014.03.003; J. Terpstra, N.R. Fyfe (see Note 32).

37 Betänkande av Polisorganisationskommittén. - En sammanhållen svensk polis ['Report for the Period 1 July 2013 to 30 June 2014 (Summary in English).']. Stockholm: Statens Offentliga Utredningar 2012; The Swedish Parliamentary Ombudsmen. Stockholm: JO Rikstagens Ombudsmän 2014.

38 J. Maesschalck (see Note 34).

39 E.g., J. Terpstra, N.R. Fyfe (as cited in Note 32 and Note 36). 
dissatisfaction with the quality of the Swedish police $\left.{ }^{*}{ }^{\circ}\right)$. From the perspective of this article, it is important to mention that one would be hard pressed to find almost any police reform that was focused on policing - that has dealt with police behaviour from the angle of police strategies (even at the corporate level).

The analysis raises the question of police professionalism: how the police can improve their reputation as safety professionals and what mechanisms could guarantee the continuous development of the police and also link the organisation to its immediate task environment.

\subsection{The dubious efficiency of employing a single strategy}

Upon analysis of the studies related to police strategies that were published in the top police-specific journals, the conclusion is quite simple: the police are presented mostly as a mono-strategy organisation. The latter is simply unrealistic - every police organisation applies many strategies simultaneously or employs techniques of diverse strategies, on different levels. The only question is about the consciousness of police action. It is likely that police action most of the time is based on an unconscious choice of various tactics or techniques, with these tactics and techniques not constituting any particular strategy. The problems that the police should handle are variously simple, complex, and wicked, and the organisation needs several strategies, in various combinations, if it is to succeed. Opportunities for this are extensive, and the only obstacle is probably related to knowledge of the associated odds. I would go even further: the meta-language of the police is based on knowledge about police strategies. The reason is quite simple - police strategies are those constitutive ties through the principles of criminology, management, and other disciplines that constitute police science. Hence, one may ask whether it is possible to be a (police) leader without understanding the meta-language of the police. It would be hard. One might also ask this: how will the police leaders mitigate wicked safety issues without understanding the possibilities for that? The field of the police embraces diverse strategies that all are necessary for contemporary policing.

Community policing is unquestionably the dominant topic in the field ${ }^{* 4}$, while subjects such as problem-oriented policing ${ }^{*} 42$, zero tolerance ${ }^{*} 43$, CompStat ${ }^{*} 44$, and intelligence-led policing ${ }^{*} 45$ have received less attention. The all-pervading characteristic that should be highlighted is the works' mono-strategic focus

40 E.g., Betänkande av Polisorganisationskommittén (Note 37).

41 See, for instance, J. Frank et al. The content of community policing: A comparison of the daily activities of community and 'beat' officers. - Policing: An International Journal of Police Strategies \& Management 20 (1997), pp. 716-728. - DOI: https://doi.org/10.1108/13639519710368116; W.M. Oliver, E. Bartgis. Community policing: A conceptual framework. Policing: An International Journal of Police Strategies \& Management 21 (1998) / 3, pp. 490-509. - DOI: https:// doi.org/10.1108/13639519810228796; D.E. Barlow, M.H. Barlow. A political economy of community policing. - Policing: An International Journal of Police Strategies \& Management 22 (1999) / 4, pp. 646-674. - DOI: https://doi. org/10.1108/13639519910299580; A. Gowri. Community policing is an epicycle. Policing: An International Journal of Police Strategies \& Management 26 (2003) / 4, pp. 591-611. - DOI: https://doi.org/10.1108/13639510310503532; P. Somerville. Understanding community policing. - Policing: An International Journal of Police Strategies \& Management 32 (2009) / 2, pp. 261-277. - DOI: https://doi.org/10.1108/13639510910958172; J.A. Ferrandino. An integrated theory for the practical application of 'governance-based policing'. - Policing: An International Journal of Police Strategies \& Management 37 (2014) / 1, pp. 52-69. - DOI: https://doi.org/10.1108/pijpsm-06-2012-0050.

42 E.g., L.G. Mazerolle, W. Terrill. Problem-oriented policing in public housing: Identifying the distribution of problem places. - Policing: An International Journal of Police Strategies \& Management 20 (1997) / 2, pp. 235-255. - DOI: https:// doi.org/10.1108/13639519710169117; P. Jesilow et al. Evaluating problem-oriented policing: A quasi-experiment. Policing: An International Journal of Police Strategies \& Management 21 (1998) / 3, pp. 449-464. - DOI: https://doi. org/10.1108/13639519810228750; G. Bichler et al. Curbing nuisance motels: An evaluation of police as place regulators. Policing: An International Journal of Police Strategies \& Management 36 (2013) / 2, pp. 437-462. - DOI: https://doi. org/10.1108/13639511311329787.

43 E.g., R.H. Burke. The socio-political context of zero tolerance policing strategies. - Policing: An International Journal of Police Strategies \& Management 21 (1998) / 4, pp. 666-682. - DOI: https://doi.org/10.1108/13639519810241683.

44 E.g., W.F. Walsh. Compstat: An analysis of an emerging police managerial paradigm. - Policing: An International Journal of Police Strategies \& Management 24 (2001) / 3, pp. 347-362. - DOI: https://doi.org/10.1108/13639510110401717; M.H. Moore, A.A. Braga. Measuring and improving police performance: The lessons of Compstat and its progeny. - Policing: An International Journal of Police Strategies \& Management 26 (2003) / 3, pp. 439-453. - DOI: https://doi. org/10.1108/13639510310489485.

45 E.g., J.H. Ratcliffe, R. Guidetti. State police investigative structure and the adoption of intelligence-led policing. - Policing: An International Journal of Police Strategies \& Management 31 (2008) / 1, pp. 109-128. - DOI: https://doi. org/10.1108/13639510810852602; L.M. Schaible, J. Sheffield, J. Intelligence-led policing and change in state law enforcement agencies. - Policing: An International Journal of Police Strategies \& Management 35 (2012) / 4, pp. 761-784. - DOI: https://doi.org/10.1108/13639511211275643. 
or, at most, comparative approach or combining of two, seldom three, strategies. In some sense, this is understandable, because each particular strategy has been developed for a particular situation. In reality, however, the police have to resolve many situations, with many differences, at the same time. For example, a police station is tasked with handling a murder case, thefts from rural properties, arson episodes in a city, drug-pushing near schools, and so on. Some of the cases extend beyond a single station's jurisdiction; some of them need to be resolved with external assistance, some are limited to quite a specific area or span of time, some of them require a top manager's personal attention, etc. There is an uncountable number of situations related to management (leadership) and also to safety, and the police should be managed in an adequate, understandable, and efficient way in view of this. Nonetheless, one can find little analysis involving multi-strategic police. Is analysis of this type too complicated to carry out? Maybe, but without there being knowledge (meta-language) of police strategies, on what should the citizens' trust in the police rest, and why should police officers have faith in the leaders of the police? What is the 'professionalism' in policing with regard to organisation and safety? How should this specific type of organisation be managed in order for the best possible results for citizens and the police organisation to come about? These blunt questions are intimately related to each other and, in combination with the facts mentioned above, illuminate the importance of police strategies in policing.

\section{An overview of the relevant theories and concepts}

Police science, proceeding partially from criminology and partly from management theories ${ }^{*}{ }^{6}$, is interdisciplinary in nature but still has a meta-language that is distinct from those of the other players in the field of safety. In the discussion below, I concentrate first on the organisation aspect, then on strategies. Both are well-developed concepts outside police science, and in combination they have strong potential to offer a solution for the problems under discussion. The purpose of this section of the chapter is to develop a mental framework for how the concept of strategy should be combined with the idea of an organisation as an open system in such a way that the possibilities in development of the police can be illuminated.

\subsection{The organisational answer to wicked problems}

Change in organisation design has often been the objective for reforming the police. I begin this subsection with an explanation of what a traditional view on an organisation, as mentioned above, consists of. Traditional organisations are 'designed for efficiency, which emphasizes vertical linkages such as hierarchy, rules and plans, and formal information systems, or toward a contemporary organization designed for learning and adaptation, which emphasizes horizontal communication and coordination'. ${ }^{4} 4$ These organisations have an internal logic that is based on fixed ties between the organisations' units and functions, as we know from the work of early organisational scholars. ${ }^{*} 48$ A history of contemporary police points back to military structures, the only example from which ideas could be readily drawn earlier in building of the police. The latter is important since we know from A.L. Stinchcombe's work ${ }^{*} 49$ that an organisation tends to maintain its initial structure. The police are still in many ways a paramilitary organisation (e.g., in the chain of command, internal hierarchical bureaucracy, ranking system, and tasks that seem to demand military-style organisation - among them detention of criminals and handling of riots). At least some elements that characterise the military ${ }^{*} 50$ can be seen, such as the following: 1 ) a centralised command structure and chain of command; 2) control exerted through the issuance of commands, directives, and orders; 3) vertical flow of communications, passing from top to bottom; 4) coercion as the method of employee motivation; 5) initiative being

46 See J.R. Greene. The Encyclopedia of Police Science, 3rd Edition, Vol. I. Routledge 2007.

47 R.L. Daft. Organization Theory and Design, 10th Edition. Mason, Ohio: Cengage Learning 2009, on p. 127.

48 See F.W. Taylor. The Principles of Scientific Management. Harper 1947; H. Fayol. General and Industrial Management. New York: Pitman 1949.

49 A.L. Stinchcombe. Social structure and organizations. - J.A. Baum, F. Dobbin (eds). Economics Meets Sociology in Strategic Management (pp. 229-259). Emerald Group Publishing Limited 2000, on p. 233.

50 S.M. Cox. Police: Practices, Perspectives, Problems. Boston: Allyn \& Bacon 1995, pp. 66-67. 
neither sought nor encouraged; 6) authoritarian leadership; 7) low tolerance for nonconformists; 8) and lack of flexibility in tackling of novel situations. These principles may be valid in connection with a simplified and very narrow view of police tasks (e.g., apprehending criminals and arranging random patrols), but the organisation that is based on the principles listed above (inherent to the concept of traditional organisation) probably comes to grief in its attempts to tackle the wicked problem of safety today. Before we go further with the discussion of organisation, the matter of wicked problems needs to be clarified.

By definition, there are no 'right' or 'wrong' solutions to wicked problems, only 'good' or 'bad' ones. ${ }^{*} 51$ Since there is no crime-free society out there, this is exactly the way in which safety should be handled. As stated by Nancy Roberts ${ }^{*} 52$, wicked problems can be distinguished from other types of problems in the following way. Simple problems enjoy consensus on the problem's definition and solution; the problemsolving here is straightforward, engendering little, if any, conflict among those involved. Solvers of complex problems, in turn, are agreed on what the problem is, but there is no consensus on how to solve the problem; while there is agreement in the problem-definition, there are unresolved issues associated with the solution. The increase in conflict makes the problem-solving process more complex. Finally, wicked problems generate extensive conflict among the stakeholders, even at high levels. In this case, there is no agreement on either the problem or its solution. The problem-solving process is further complicated because stakeholders in a democratic society have the power to block initiatives not of their liking through lawsuits, judicial review, and the time-honoured tradition of throwing those 'rascals' out of office. Nothing really bounds the problem-solving process - it is experienced as ambiguous, fluid, complex, politically fraught, and frustrating as hell. In this kind of situation, co-operation and communication are the catchwords for what to pursue.

Safety in modern times has been defined as a wicked problem. This means that there are no solutions there are only mitigation measures and choices that have to be made in every single case and should always be considered in their particular context. The context of safety as described above requires an appropriate mentality for describing organisations. Instead of thinking in traditional terms, with hierarchical wellstructured organisations that are designed for solving simple or complex problems and that have rigid, tightly fixed units or functions, we should turn to an organisation as a system (whether open or closed). Although the latter is a seldom-used concept in police literature, there are significant exceptions. Cordner and Kathryn E. Scarborough ${ }^{*} 53$ are scholars who, among others, have made a great contribution to police science from the organisational perspective. Their Police Administration ${ }^{*} 54$ is one of the truly remarkable books in the field of policing, offering a description of organisation as system. From this book the reader will get an overview of an organisation as a system, and the focus is placed on police organisation: 'Police departments are systems no more or less complex than other organizational systems. Police organizations consist of numerous involved, interdependent subsystems. ${ }^{*} 55$ The purpose of the present article, however, is not narrowly confined to the organisation perspective; I take a more sociological line. Therefore, a wider view is needed. The reason for this stems from the core mission of the police - the police should deal with questions of safety, many of which are bound to be wicked today. In this sense, the police are always as a tool in the hands of a government that has specific strategies and techniques. At the same time, the police are only one actor of many in a social system, and since the questions of safety cut through all aspects of society, the police should be treated as a part of that particular society. It is for this reason that I move outward from a narrow focus on an organisation to more sociologically oriented explanations. In this article, I trace the ecological level of analysis and compass an organisation as a collective entity operating in a larger system of relations. ${ }^{*}{ }^{6}$ At this point, the organisation is viewed as an open system. The open-system view of organisational structure places emphasis on the complexity and variability of the individual parts - both individual participants and subgroups - as well as the looseness of connections among them. Parts are

51 P. Selg. 'The fable of the Bs': Between substantialism and deep relational thinking about power. - Journal of Political Power 9 (2016) / 2, pp. 183-204, on p. 18. - DOI: https://doi.org/10.1080/2158379x.2016.1191163; H.W. Rittel, M.M. Webber (see Note 5).

52 N. Roberts. Wicked problems and network approaches to resolution. - International Public Management Review 1 (2000) / 1, pp. 1-2.

53 G.W. Cordner, K.E. Scarborough (see Note 26).

54 Ibid.

55 Ibid., p. 59.

56 See J.A. Baum. Organizational ecology. - S.R. Clegg et al. (eds). Studying Organization: Theory and Method (pp. 71-108). 1999. 
viewed as capable of semiautonomous action; many parts are viewed as, at best, loosely joined to other parts. In such an organisation, participants - groups and individuals - form and leave coalitions; there is continual flux of relations. ${ }^{*} 57$ Thus, the organisation itself (the inherent logic) and its relations to the task environment have a deeply interdependent character. But what are the ties internal to an organisation but also between that organisation and its environment that 1) bind actors within the organisation, 2) make possible a flexible relationship between organisation and environment, 3) guarantee appropriate answers in attempts to solve or mitigate safety problems, and 4) provide an organisational context for continuous advancement as a professional organisation? In this article, I argue that these ties can take the form of police strategies.

\subsection{The essential role of safety-oriented strategies in police organisation}

In the field of management, strategic management is the discipline embracing both organisation and strategy. From that perspective and tying in with the topic of the article, the principles of strategic management are 'youthful' ${ }^{*} 8$ and have taken several agile turns, from looking for best practices to concepts such as competition or relationalism in and between organisation(s) and environments. Although we can draw many parallels between the strategic management discipline and developments in the field of police strategies, these discussions remain for the future. Since the purpose of this article is to create a mental framework that could help police leaders and educators advance the police's ability to be a professional player in the field of safety, this section focuses on a role for strategies in police organisation and a role for safety, but not on precise strategies. Although the latter matter requires further attention ${ }^{*} 59$, the more extensive elaboration on it required would exceed the limits for this article.

In traditional organisations designed for efficient performance, a strategy is formulated by top managers and imposed on the organisation. ${ }^{*}{ }^{60}$ This description reveals a particular problem that is intrinsic for many organisations, including the police: organisations are often seen as mono-strategic (see Subsection 2.2, above). To some extent, they may have this nature inherently but only on the corporate level. It is hard even to imagine that any organisation could truly use only one strategy or even apply no strategy at all. If an organisation does not have any obvious and clearly expressed strategy, if its leaders do not have good knowledge of strategies related to the organisation and its task environment, tragedy could readily result for the organisation, its members, and clients alike. For avoidance of such a tragedy, the meaning and possibilities of strategies are in need of being clarified. That is the reason for this article.

To stay in line with the sociological institutionalism, particularly with Kenneth Scott's ${ }^{* 61}$ view on it, this section is focused on techniques that should address the questions posed at the outset.

For any organisation, it is relatively easy for one to determine core activities to which the focal work of that body is connected. Teaching in schools, health care in hospitals, and helping people and solving safety problems in the police are only a few examples of the core activities in various fields. However, every organisation has a technical core, as James Thompson's ${ }^{* 62}$ seminal book indicates. This means, in turn, that each organisations has some resource that is critical to its mission. These resources may be material (such as cars or computers) and/or mental (as with knowledge, software, and meta-language), and every organisation has two - in some respects inconsistent - responsibilities connected to its technical core. Firstly, these central resources need to be protected from the turbulent environment. Secondly, the efforts to protect them must not be extended too far, because they need adequate information and energy in order to survive. Scott puts it thus ${ }^{*} 63:$ 'Organizations must both distinguish their systems from and connect themselves to

57 W.R. Scott. Organizations: Rational, Natural, and Open Systems. New Jersey: Prentice-Hall 2003, p. 101.

58 See L.Á. Guerras-Martín et al. The evolution of strategic management research: Recent trends and current directions. $-B R Q$ Business Research Quarterly 17 (2014) / 2, pp. 69-76. - DOI: https://doi.org/10.1016/j.brq.2014.03.001.

59 P. Suve et al. Designing multidimensional policing strategy and organization: Towards a synthesis of professional and community police models. - Baltic Journal of Law \& Politics 8 (2015) / 1, pp. 28-54. - DOI: https://doi.org/10.1515/ bjlp-2015-0010.

60 R.L. Daft (see Note 47), p. 33.

61 W.R. Scott (see Note 57).

62 J.D. Thompson. Organizations in Action: Social Science Bases of Administrative Theory. Transaction Publishers 1967.

63 W.R. Scott (see Note 57), p. 124. 
their environment. Boundary-defining mechanisms as well as the tactics used by organizations to buffer their technical core and to build bridges to other organizations.' The term denoting those tactics that protect a technical core from the turbulent environment is 'buffering', and 'bridging' is the term denoting tactics for crossing the gap between the organisation and the environment. ${ }^{* 64}$ To crystallise this idea, some widespread tactics linked to the terms mentioned above will be briefly introduced below.

I will start with the concept of buffering tactics ${ }^{*} 65$. Coding is probably the most well-known of these tactics. It is important for any organisation to select and control every source that will be used by the technical core. In schools, a pupil's age and knowledge should be checked before he or she is assigned to a particular class, a car spare should be checked before pinning up, a drunken juvenile is taken home instead of to prison with a murderer, and so on. To survive and develop, an organisation needs to have several 'stocks'. A hospital needs syringes and fresh blood; the police need weapons and personnel for the emergencies that arise in the course of their operations, in turn; all organisations need to train new leaders; etc. Also, every organisation deals with forecasting. Many examples could be cited: schools need to know the demographic situation, a company that sells cars must forecast people's needs and tastes, the police predict possible crime hot-spots, and so on.

While buffering tactics are employed mainly for protecting the technical core, bridging tactics ${ }^{* 66}$ are designed to protect the entire organisation. To survive, the organisation needs energy and information from its environment. Interdependence characterises an organisation from both an internal and an external perspective. That means that no organisation exists without interdependent connections between it and other organisations, and extending to and from the environment. Therefore, to survive, organisations need information from other organisations in the field (e.g., about trends and the market situation) but also energy (e.g., new staff and knowledge) from their environment. The problem is this: organisations do not control the above-mentioned resources that are so vital for them. Since bridging techniques are tightly coupled with resources that are needed if the organisation is going to survive, Jeffrey Pfeffer and Gerald R. Salancik's ${ }^{* 67}$ ideas about this topic are probably cited most often in this connection. One of the most commonly used tactics is bargaining (Scott calls it "pre-bridging tactics" ${ }^{* 68}$ ). Through a bargaining process, organisations try to avoid complete dependence on a partner but strive to cultivate the best possible conditions or sources. The crucial element here is knowledge of one's own priorities and interests. There are many problems in the field of safety, in which the responsibility of related players is far from clear but precise roles need to be clarified. Close to bargaining tactics is contracting - engaging in negotiation on something that is going to appear in the future. Although the scope in contracting is unlimited, from the perspective of this article the opportunity for coalitions of various sorts should be highlighted. These coalitions may be preventive and/or reactive (post factum) in nature. Merger is the most topical tactic in the context of the police reforms described above. In the pursuit of being more effective and efficient, the trend of merging police units is well-known. However, the process of merging is not used only at the organisational level; it is applied also on strategic level. Public-private partnership ${ }^{*} 69$ is the well-known police strategy aimed at dividing resources between the police and partners from the private sector.

64 Ibid., p. 199.

65 See, for example, J.G. March, H.A. Simon. Organizations. New York: Wiley 1993; W.R. Scott (see Note 57); C. Oliver. Strategic responses to institutional processes. - Academy of Management Review 16 (1991) / 1, pp. 145-179. - DOI: https://doi. org/10.5465/amr.1991.4279002.

66 See, among others, A.D. Meyer et al. Environmental jolts and industry revolutions: Organizational responses to discontinuous change. - Strategic Management Journal 11 (1990), pp. 93-110; M.F. DiPaola, M. Tschannen-Moran. Bridging or buffering? The impact of schools' adaptive strategies on student achievement. - Journal of Educational Administration 43 (2005) / 1, pp. 60-71. - DOI: https://doi.org/10.1108/09578230510577290; W.R. Scott (see Note 57).

67 J. Pfeffer, G.R. Salancik. The External Control of Organizations: A Resource Dependence Perspective. Stanford University Press 2003.

68 W.R. Scott (see Note 57), p. 204.

69 See, for example, D. Das et al. The changing 'soul' of Dutch policing: Responses to new security demands and the relationship with Dutch tradition. - Policing: An International Journal of Police Strategies \& Management 30 (2007) / 3, pp. 518-532. - DOI: https://doi.org/10.1108/13639510710778877; E.S. Savas, E.S. Savas. Privatization and Public-Private Partnerships. New York: Chatham House 2000; P. Ponsaers. Reading about 'community (oriented) policing' and police models. - Policing: An International Journal of Police Strategies \& Management 24 (2001) / 4, pp. 470-497. - DOI: https://doi.org/10.1108/eum0000000006496; J. Terpstra, K. van der Vijver. The police, changing security arrangements and late modernity: The case of the Netherlands. - German Policy Studies 3 (2006) / 1, p. 80. 
In summary of this section, it should be highlighted that the core of any organisation needs to be protected; to survive, an organisation needs information and energy from its environment, and there are many tactics available that should be of assistance for these purposes. However, something remains missing. This is something particular to every organisation and field. As I have stated earlier in the article, in a key part of my argument, police strategies are the means that breathes a meaning and real soul into the buffering and bridging strategies in this domain specifically. The argument is given a contextual explanation via the concluding thoughts below.

\section{Conclusions}

The article had two central questions to answer. Firstly, how should the concept of the organisation be handled such that it at least offers a chance of mitigating wicked problems? Secondly, what are these mechanisms that could develop the police's professional status in society and simultaneously act as a tie organisation-internally while also connecting the organisation to its existing task environment?

Contemporary organisational theories offer several tools for connecting an organisation with its task environment, but the buffering and bridging mechanisms are one of the most expedient choices for protecting an organisation's technical core and linking the organisation to its task environment. Since the purpose behind this article was to create a mental framework that could help police leaders and educators to advance the police's ability to serve as the professional player in the field of safety, I use my concluding thoughts to elaborate on and outline that framework.

It is evident already that, for addressing wicked problems, the police should be treated as an open system. The latter does not mean that the organisation is devoid of boundaries. It has boundaries, but they are blurry in comparison to the traditional conceptualisation of an organisation as a closed system. Designing a police organisation as an open system means that the organisation is a 'compendium of' various groups (individual units, police stations, etc.), alliances (e.g., informal coalitions or working groups), and/or functions (e.g., law enforcement, forensics, and criminal-police personnel). The above-mentioned entities, in turn, have their own subgroups or sub-alliances, which engage in mixed and interdependent relations with each other. Therefore, this kind of organisation needs to be protected from external turbulence too but must still be designed to be innovative in the sense of advancing the police profession and responding to emergent phenomena. Mono-strategic police are too limited to tackle contemporary safety issues. For this reason, the police profession - in its language, use of multiple strategies or techniques simultaneously, and so forth - and its particulars always must be borne in mind when reforms to the police are undertaken. Only then can hope of mitigating wicked safety problems remain alive. Before one looks at the police from the standpoint of safety, contextualisation in terms of buffering and bridging techniques is a helpful leadin. Without going into depth, it is enough for this article to give a few examples to assist in visualising or imagining the context of the police. In protecting their technical core, the police employ buffering strategies such as coding (e.g., specialised work flows), stockpiling (e.g., recruitment, retraining, and use of special equipment), and forecasting (e.g., crime analysis and use of geographical information systems). To receive information and energy from the task environment and to protect the entire organisation from external impacts, the police organisation utilises diverse bridging techniques. The following are just some of them: bargaining (e.g., surrounding whose responsibility it is to maintain public order at nearby bars and restaurants), contracting (e.g., agreements between the police and the local municipality), and joint ventures (e.g., co-operation with schools on lectures aimed at crime-prevention or for dealing with drug use). Both buffering and bridging techniques have countless examples, but for now it suffices to specify thus: these techniques always have an occupation-specific nature. That means that there is always some meta-language or coding system that needs to be recognised. The police have a particular meta-language, which (in a parallel to police science) has been generated by at least two distinct disciplines - criminology and management. Finally, police strategies can be added to the map. Police strategies are the focal points or the coupling points between criminology and management principles - they form the essence of the meta-language. Hence, all buffering and bridging techniques should be handled through appropriate police strategy at the proper level in the organisation and in a particular, appropriate context. There is no right answer - only continuous experimentation with various combinations can lead the organisation towards success in dealing with organisational as well as safety problems. 
Priit Suve

Police strategies form an essential part of the police's meta-language, a tie within the organisation and between the police force and its task environment. Lastly but not least, those strategies hold the key to mitigating wicked problems. If we are to prevent de-professionalisation in times of reform, rooted in neglect of safety issues, police strategies should be taken as the essential elements in linking the police institution to its task environment and holding the police in line with their core mission. The meta-language could be the indicator that expresses the level of policing professionalisation within the police. 